\title{
Analysis on Students' Learning Readiness in Junior High Schools of Pangkalpinang, Bangka Belitung
}

\author{
Ganis Amurdawati ${ }^{1}$, Suyatno ${ }^{2, *}$, Dholina Inang Pambudi ${ }^{3}$, Wantini ${ }^{4}$, Maulina Hendrik ${ }^{5}$ \\ ${ }^{1}$ Department of Primary Teacher Education, Universitas Negeri Semarang, Indonesia \\ ${ }^{2}$ Department of Education Management, Universitas Ahmad Dahlan, Indonesia \\ ${ }^{3}$ Department of Primary Teacher Education, Universitas Ahmad Dahlan, Indonesia \\ ${ }^{4}$ Department of Islamic Education, Universitas Ahmad Dahlan, Indonesia \\ ${ }^{5}$ Department of Primary Teacher Education, STKIP Muhammadiyah Bangka Belitung, Indonesia
}

Received April 1, 2020; Revised May 11, 2020; Accepted June 4, 2020

\section{Cite This Paper in the following Citation Styles}

(a): [1] Ganis Amurdawati, Suyatno, Dholina Inang Pambudi, Wantini, Maulina Hendrik , "Analysis on Students' Learning Readiness in Junior High Schools of Pangkalpinang, Bangka Belitung," Universal Journal of Educational Research, Vol. 8, No. 9, pp. 3807 - 3813, 2020. DOI: 10.13189/ujer.2020.080903.

(b): Ganis Amurdawati, Suyatno, Dholina Inang Pambudi, Wantini, Maulina Hendrik (2020). Analysis on Students' Learning Readiness in Junior High Schools of Pangkalpinang, Bangka Belitung. Universal Journal of Educational Research, 8(9), 3807 - 3813. DOI: 10.13189/ujer.2020.080903.

Copyright $@ 2020$ by authors, all rights reserved. Authors agree that this article remains permanently open access under the terms of the Creative Commons Attribution License 4.0 International License

\begin{abstract}
Learning readiness is one of the indicators supporting students' learning achievement. The higher the students' learning readiness is, the higher their possibility is to achieve the learning outcome. The purpose of the research is to analyze the students' learning readiness in several junior high schools in Pangkalpinang City, Bangka Belitung Island, Indonesia. The study belongs to a survey study with a cross-sectional design investigating 150 students from three junior high schools, both private and public. The data were collected through a questionnaire and they were analyzed using SPSS with one-way ANOVA and independent sample t-test. The results show that there is no difference in the students' readiness in two public junior high schools, those are SMP N 1 Pangkalpinang and SMP N 7 Pangkalpinang, with the sig value $0.568>0.05$. Conversely, there is a difference in the learning readiness between the private and public schools, which is between SMP N 1 Pangkalpinang and SMP Muh Pangkalpinang as well as between SMP N 7 Pangkalpinang and SMP Muh Pangkalpinang, with sig value $0.000<0.05$. Meanwhile, the $t$-test for the gender comparison shows no difference in terms of learning readiness, with the sig value $0.663>0.05$. The research comes to several conclusions. First, the school status (public and private) shows a difference in learning readiness, in that those in public schools have higher readiness compared to those in private schools.
\end{abstract}

Second, male and female students show similarities in terms of learning readiness.

Keywords Learning Readiness, Junior High School, Gender, School Status

\section{Introduction}

Facing the challenges of the twenty-first century requires our readiness in any situation. Education plays an important role in helping an individual to prepare himself for the challenges (DiBenendetto \& Myers, 2016). Other than the readiness in the career and the social environment, learning readiness is also necessary for the students in an attempt to obtain new knowledge and experience. On the other hand, there is a gap between students and educators in efforts to develop the skills in the century (Robbins, 2017). Therefore, students' readiness becomes a concern for the sake of their learning success.

The success of the learning process is influenced by several factors, both external and internal. Learning readiness is one of the internal factors for the students' success (Payne et al., 2008), allowing them to gain new experience. Curenton (2010) explained that the students' 
success at school depends on their readiness along with the skills obtained in several domains, such as academic, physical, and social-emotional domains. Meanwhile, Breathnach and Stephenson (2011) state that the gaining of experience and success needs mature learning readiness of various factors, coming from the educators as well as from the targeted experience.

Ramlan et al. (2019) propose that readiness and learning interest are significant indicators for the success of education. Similar to the idea, Vasilevska et al. (2017) reveal the differences in the students' readiness in following distance education. In addition, the study concludes that there was no evaluation of the students' readiness for the distance model. Similarly, in their study, Kaymak and Horzum (2013) explain the importance of students' readiness for online learning, particularly about the structure that influences the students' learning outcome and interaction. Meanwhile, Mulyani (2013) conducted descriptive correlational research and the result revealed that there is a correlation between students' learning readiness and their learning achievement. Further, physical, social, and emotional development, as well as self-efficacy will influence the students' maturity (Lema \& Agrusa, 2007). In addition, students' health is another intrinsic component to be taken care of by the educators for the success of teaching (Tretyakova et al., 2016).

Learning readiness helps students to receive various things in order to achieve the standard mastery. Every student has different levels of readiness. Unfortunately, the teacher often ignores the fact. Some teachers teach without considering the students' readiness. The present study found that learning readiness is distinguished based on gender and school status. The distinction occurs in junior high schools in Pangkalpinang City, Bangka Belitung Island. Previous studies have not focused on the students' learning readiness, particularly the one that is classified based on gender and school status (Tomlinson et al., 2003). The study is significant to help the schools, local government, teachers, and educational practitioners get more insight into the factors influencing students' readiness, allowing them to implement proper policy.

\section{Literature Review}

\subsection{The Concept of Learning Readiness}

Learning readiness is the prerequisite condition for an effective teaching and learning process at school. There are two models in the concept of readiness. They are readiness for learning and readiness for school. According to Hilfery and Redmond (2010), readiness for school is defined as limited construction that refers to the necessary knowledge and skills to achieve success at school. Different from this concept, readiness for learning has a broader meaning, that is, the child can develop and learn at different stages in their life. Learning in this concept is seen as continuous and multisided. Besides, it combines the physical welfare of the children as well as their motor, social, emotional, linguistic, and cognitive development. Jensen (1969) explained that the students' readiness for learning includes cumulative learning, sub-skills, components, and development maturity that are necessary to integrate the sub-skills into the targeted skills. Murray and Harrison (2011) stated that the decision of 'readiness' is related to the identification of the students' competence and their specific capabilities that are needed for school. To prepare the students' readiness, these aspects are necessary to consider. To put it simply, a child who is ready for school has the basic skills and knowledge in various domains that allow them to succeed at school (UNICEF, 2012).

Thorndike's readiness law (in Prakash, 2012) suggested that readiness is a mental condition where a child can learn the subject when he has the willingness to do it. Meanwhile, Billett (2018), in his study, found that readiness includes everything that is acknowledged and done by the students. He added that readiness also means the values that link the students' understanding to their experience and then enable them to integrate the experiences to achieve successful learning (the ability to adapt). Furthermore, learning readiness needs to consider the social development of the students as well as their intellectual background (Katz, 1991).

\subsection{Factors that Influence the Students' Learning Readiness}

Students' readiness in learning has been discussed since the 1980s. Ansari and Coch (2006) revealed that social-economic status, language, limited problem-solving strategy, and parents' involvement highly influence a student's readiness. Meanwhile, the underlying factors of learning readiness include the environment, parents' responsibility, and teachers' responsibility. Perry et al. (1998) stated that parents help children in preparing for the school while teachers' roles are related to the teaching and learning process at school. Further, Janus and Duku (2007) proposed five aspects of learning readiness in developing the students' literacy: social-economic status, family condition, the students' health, the parents' health, and parents' involvement. Although family characteristics have the biggest significance in shaping the students' readiness, the environment, independently, is related to the early development (physic and welfare), linguistic and cognitive development, and communication, as well as skills and common knowledge of the student (Oliver et al., 2007).

Self-confidence, motivation, and achievement of the students are greatly influenced by their readiness in learning (Dangol \& Sherestha, 2019; Moyer, 2011; Kearney \& Garfield, 2019; Samarawikcrema, 2005; Grace 
\& Brandt, 2006). It indicates that a low level of students' readiness may lessen the effectiveness of the teaching and learning process. Students' readiness influences educators in determining the learning objectives (Weinstein \& Wu, 2009; Xu et al, 2017). Other studies prove that learning materials and strategies also affect the improvement of the students' readiness (Brigman \& Webb, 2003). Learning readiness provides students with the necessary skills, thereby preventing them from future failure. Besides, Grigoryeva (2019) stated that students' readiness for changes influences the level of their social activities.

By considering several factors, schools carry out various components to improve students' learning readiness. Mardati et al. (2019) explained that the teachers' value and leadership become significant factors that influence the students' readiness. The higher the leadership and the values is, the higher the students' learning readiness is. Readiness includes motivation, development, and attention aspect.

\section{Research Methods}

\subsection{Research Design}

The research belongs to the quantitative type using a cross-sectional survey design. It is carried out by collecting the data at a particular time from the samples (Cresswell, 2012). The design was employed to measure the behavior of the population concerning the levels of students' readiness, which become the variable of the study. The design is chosen because it can immediately present the necessary information.

\subsection{Participants}

The population of the research is the students of the junior high schools in Pangkalpinang City, Bangka Belitung Island, Indonesia. From the population, the samples were taken using random sampling technique, which resulted in the selection of three schools (SMP N 1 Pangkalpinang, SMP N 7 Pangkalpinang, and SMP Muh Pangkalpinang). From the selected schools, 150 students from grade 7 and 8 were taken as the samples.

\subsection{Technique of Collecting and Analyzing the Data}

The data were collected through questionnaires. The instrument is the questionnaire containing items of questions developed from the indicators. The questionnaire has been used before and has been tested by the expert judgment and validated through an empiric test in the field. The data were then analyzed using ANOVA Post Hoc test using Scheffe's test technique to analyze the school status; while independent sample t-test is to analyze the gender difference. All of the techniques are carried out using SPSS 20.0 software.

\section{Findings}

\section{Result of Prerequisite Test}

The prerequisite test was carried out before finding the result of the research hypothesis. The test consists of a normality test and homogeneity test using SPSS 21.0. The normality-test result is shown in table 1.

Table 1. Results of Normality Test

\begin{tabular}{llccc}
\hline \multicolumn{4}{c}{ Tests of Normality } \\
\hline \multirow{3}{*}{ Grade School } & \multicolumn{3}{c}{ Shapiro-Wilk } \\
\cline { 2 - 5 } & & Statistic & df & Sig. \\
\hline \multirow{2}{*}{ Sata_Grade } & SMP Muh PKP & .965 & 49 & .151 \\
\cline { 2 - 5 } & SMP N 7 PKP & .975 & 51 & .359 \\
\cline { 2 - 5 } & SMP N 1 PKP & .981 & 50 & .583 \\
\hline *. This is a lower bound of the true significance. \\
\hline a. Lilliefors Significance Correction \\
\hline
\end{tabular}

Based on table 1, the sig. value of Shapiro-wilk on day three is higher than the significance level of 0.05 . Thus, it can be concluded that the data are normally distributed. The steps are proceeded with the homogeneity test, of which the result of the test is shown in table 2. Table 2 shows the Lavene Statistic value 0.540 with Sig. value $0.584>0.05$. Thus, it can be concluded that the variants among groups are similar or homogenous. Both prerequisite tests have fulfilled the requirements for hypothesis analysis because the data were normally distributed and homogeneous. The hypothesis test was carried out to analyze the difference in the students' learning readiness from the variable of school status and gender.

Table 2. Results of Homogeneity Test

\begin{tabular}{cccc}
\hline \multicolumn{5}{c}{ Test of Homogeneity of Variances } \\
\hline \multicolumn{5}{c}{ Data_Grade } \\
\hline Levene Statistic & df1 & df2 & Sig. \\
\hline .540 & 2 & 147 & .584 \\
\hline
\end{tabular}

\section{First Hypothesis Test (T-test for each school)}

The analysis is aimed to describe the readiness of each school. Through ANOVA and Post Hoc tests, the schools under study are found to have different levels of readiness. The following are the results of ANOVA and Post Hoc using SPSS 21.0.

Based on the tabel 3, it is known that the mean scores of three schools are different. The first place is occupied by SMP N 1 Pangkalpinang with the mean of 99.40. The second is SMP N 7 Pangkalpinang with the mean of 96.80 . Meanwhile, the last is occupied by SMP Muhammadiyah Pangkalpinang with the mean of 82.41. The total mean score is 92.97. Before taking the ANOVA test, prerequisite tests were carried out. 
Table 3. Descriptive analysis results of the statistics

\begin{tabular}{ccccc}
\hline \multicolumn{5}{c}{ Descriptive } \\
\hline Data Grade & N & Mean & $\begin{array}{c}\text { Std. } \\
\text { Deviation }\end{array}$ & Std. Error \\
\hline SMP N 1 PKP & 50 & 99.40 & 12.825 & 1.814 \\
\hline SMP N 7 PKP & 51 & 96.80 & 12.058 & 1.688 \\
\hline SMP Muh PKP & 49 & 82.41 & 11.783 & 1.683 \\
\hline Total & 150 & 92.97 & 14.255 & 1.164
\end{tabular}

Table 4 shows the difference in terms of readiness among schools under study. The table 4 shows the results of the t-test using one-way ANOVA, with the sig. value $0.00<0.05$, meaning that the three schools have relatively different levels of readiness.

Table 4. T-test result of learning readiness of each school

\begin{tabular}{cccccc}
\hline \multicolumn{5}{c}{ ANOVA } \\
\hline & $\begin{array}{c}\text { Sum of } \\
\text { Squares }\end{array}$ & df & Mean Square & F & Sig. \\
\hline $\begin{array}{c}\text { Between } \\
\text { Groups }\end{array}$ & 8282.957 & 2 & 4141.479 & 27.680 & .000 \\
\hline $\begin{array}{c}\text { Within } \\
\text { Groups }\end{array}$ & 21993.876 & 147 & 149.618 & & \\
\hline Total & 30276.833 & 149 & & \\
\hline
\end{tabular}

Meanwhile, to compare the readiness of each school, the Post Hoc test was carried out using the Scheffe Technique, which is shown in table 5. Table 5 compares the learning readiness of the three schools under study. It is known that the sig.value between SMP Muh Pangkalpinang and SMP $\mathrm{N} 7$ Pangkalpinang is $0.000<0.05$. It means that the average score for the difference is -14.396 with a confidence level of $95 \%$. Similarly, the sig value for the t-test of SMP Muh Pangkalpinang and SMP N 1 Pangkalpinang is $0.000<0.05$. Hence, the two schools are different with the mean score of 16.992 and the confidence level of $95 \%$.

Table 5. Results of T-test of each school

\begin{tabular}{lllll}
\hline \multicolumn{4}{c}{ Multiple Comparisons } \\
\hline \multicolumn{4}{c}{ Dependent Variable: Data_Grade Scheffe } \\
\hline \multirow{2}{*}{$\begin{array}{c}\text { (I) Grade School } \\
\text { (J) Grade } \\
\text { School }\end{array}$} & $\begin{array}{c}\text { Mean } \\
\text { Difference } \\
\text { (I-J) }\end{array}$ & Std. Error & Sig. \\
\hline \multirow{2}{*}{ SMP Muh PKP } & SMP N 7 PKP & $-14.396^{*}$ & 2.447 & .000 \\
\cline { 2 - 5 } & SMP N 1 PKP & $-16.992^{*}$ & 2.459 & .000 \\
\hline \multirow{2}{*}{ SMP N 7 PKP } & SMP Muh PKP & $14.396^{*}$ & 2.447 & .000 \\
\cline { 2 - 5 } & SMP N 1 PKP & -2.596 & 2.434 & .568 \\
\hline \multirow{2}{*}{ SMP N 1 PKP } & SMP Muh PKP & $16.992^{*}$ & 2.459 & .000 \\
\cline { 2 - 5 } & SMP N 7 PKP & 2.596 & 2.434 & .568 \\
\hline *. The mean difference is significant at the 0.05 level.
\end{tabular}

Meanwhile, the sig value between SMP $\mathrm{N} \quad 7$ Pangkalpinang and SMP N 1 Pangkalpinang is $0.568>$
0.05. The result shows that both two schools are not different in terms of learning readiness. The t-test revealed that the two public schools are not different, while they show different scores when each is compared to the private school, which is SMP Muhammadiyah Pangkalpinang. The t-test is presented in table 6.

Table 6. T-test of Learning Readiness based on the School Status

\begin{tabular}{ccc}
\hline School Name & Sig value & Explanation \\
\hline $\begin{array}{c}\text { SMP N 1 PKP with } \\
\text { SMP N 7 PKP }\end{array}$ & $0,568>0,05$ & No diferrence \\
\hline $\begin{array}{c}\text { SMP N 1 PKP with } \\
\text { SMP Muh PKP }\end{array}$ & $0,000<0,05$ & Diferrence \\
\hline $\begin{array}{c}\text { SMP N 7 PKP wih } \\
\text { SMP Muh PKP }\end{array}$ & $0,000<0,05$ & difference \\
\hline
\end{tabular}

\section{Second Hypothesis Test (T-test of learning Readiness based on Gender)}

The test is aimed to know the difference in terms of learning readiness based on gender. The second analysis employed an independent sample t-test, of which the result is presented in table 7 .

From the table 7, it is known that the number of female respondents is 84 , while the male is 66 . The mean score of both genders is different. Female students reached the score of 93.60, higher than the male (92.94).

Table 7. Statistic Descriptive Result based on Gender

\begin{tabular}{cccccc}
\hline \multicolumn{6}{c}{ Group Statistics } \\
\hline & Gender & N & Mean & Std. Deviation & $\begin{array}{c}\text { Std. Error } \\
\text { Mean }\end{array}$ \\
\hline $\begin{array}{c}\text { Data } \\
\text { Gender }\end{array}$ & Female & 84 & 93.60 & 13.652 & 1.490 \\
\cline { 2 - 6 } & Male & 66 & 92.94 & 14.543 & 1.790 \\
\hline
\end{tabular}

The result was further tested and the score can be seen in table 8. Table 8 shows the significance level of 0.656 compared to the sig rate of 0.05 . Thus, it can be concluded that male and female students have the same level of readiness.

Table 8. Test Result of Learning Readiness Based on Gender

\begin{tabular}{cccccc}
\hline \multicolumn{5}{c}{ Independent Samples Test } \\
\hline \multicolumn{5}{c}{ t-test for Equality of Means } \\
\hline & $\mathrm{t}$ & $\mathrm{df}$ & $\begin{array}{c}\text { Sig. } \\
\text { (2-tailed) }\end{array}$ & $\begin{array}{c}\text { Mean } \\
\text { Difference }\end{array}$ & $\begin{array}{c}\text { Std. Error } \\
\text { Difference }\end{array}$ \\
\hline $\begin{array}{c}\text { Equal } \\
\text { variances } \\
\text { assumed }\end{array}$ & .284 & 148 & .777 & .656 & 2.311 \\
\hline $\begin{array}{c}\text { Equal } \\
\text { variances not } \\
\text { assumed }\end{array}$ & .282 & 135.356 & .779 & .656 & 2.329 \\
\hline
\end{tabular}

\section{Discussion}

The result revealed two points. The first is the students' learning readiness in private and public schools, and the 
second is the learning readiness of male and female students. From the result, in this research, public school students are more ready compared to the ones in private schools. In addition, male and female students show the same level of learning readiness.

The first finding shows that male and female students show similar level of readiness. It is caused by their similarity in the aspect of thinking skills and learning habits (UNICEF, 2002). It contributes to the references about learning readiness, showing that male and female students are equal in the educational aspect. This is apart from the physical difference between two genders. The result is similar to the study conducted by Schnepf and Sylke (2004), mentioning that gender does not significantly influence learning readiness. The result supported the study conducted by Gee (2015), which correlates the learning readiness to students' achievement. The mean score between male and female students are equal in four fields of study: literacy, calculation, natural science, and social science.

Although the analysis shows that the male and female students' readiness is similar, gender equality needs to be integrated into the classroom to contribute to the improvement of the students' academic performance (Hernandez \& Cudiamat, 2018). Besides, the main challenge in relation to gender in education is to go beyond documenting the effect of gender differences (Jacobs, 1996). Further, gender will give different effects on each individual's readiness for learning.

The second finding reveals that students from schools having different status have different readiness in learning. The results show that the comparison of two public schools, which are SMP N 1 Pangkalpinang and SMP N 7 Pangkalpinang, proves that there is no difference in terms of learning readiness. Meanwhile, when each public school is compared to the private school, SMP Muhammadiyah Pangkalpinang, it is evident that the students in public schools are more ready to learn. Based on the score of readiness, SMP N 1 Pangkalpinang is in the first place, followed by SMP N 7 Pangkalpinang. Thus, SMP Muhammadiyah Pangkalpinang reached the lowest score of learning readiness.

The analysis of the present study combined with the previous studies revealed that the difference in the students' learning readiness is not caused by the school status. Public schools prove to build better students' learning readiness (Dronkers \& Robert, 2008; Brunello \& Rocco, 2008; Iqbal, 2012) because they have better input of the students, better classroom climate, better service quality, and more professional school management. Meanwhile, other studies also found that the students' learning readiness in private schools is better (Mancebón \& Muñiz, 2008; Urquiola, 2016; Fidana \& Ozturk, 2015) because the students have a better family background and the teachers are more creative and highly motivated. In short, the key factors of learning readiness include the students' capability, social composition, classroom climate, school service, motivated and creative teachers, better facilities, and professional staff. In addition, Barrera-Osorio et al. (2020) reported that the increase of students' performance is related to the improvement of the input availability, as well as a positive selection from the government in helping students in private schools.

Schools need to arrange long-term plans to improve students' learning readiness. Kartal and Balcikanli (2019) proposed that it is important to investigate the students' readiness since it turned out that teachers can create a comfortable learning environment for the students. Improvement of the teachers' values in the learning process is necessary to create better classroom learning climate (Suyatno et al., 2019a; 2019b). Good classroom climate is expected to be one of the key factors in improving the students' learning readiness.

\section{Conclusions}

To sum up, the school status (public and private) influences the learning readiness of the students. Those in public schools are more ready compared to those in the private one. Meanwhile, gender does not cause any difference. From the theories and the results of previous studies, it can be concluded that the differences are not caused by the school status. Instead, they are from the attributes owned by the schools, for example, potential students, social composition, school climate, and school services. Besides, motivated and creative teachers should be taken into account, in that they always try to find new methods in teaching. Furthermore, the school quality cannot be separated from the qualified staff, allowing the schools to have better management. All of these are the support system for the students' learning readiness.

\section{Acknowledgements}

The researchers would like to express the special gratitude to the Directorate General of Research and Education of the Ministry of Research, Technology, and Higher Education for providing us the full funding for the research through fundamental excellence research grants for higher education (PDUPT-Penelitian Dasar Unggulan Perguruan Tinggi).

\section{REFERENCES}

[1] Ansari, D., \& Coch, D. (2006). Bridges over troubled waters: Education and cognitive neuroscience. Trends in cognitive sciences, 10(4), 146-151. 
[2] Barrera-Osorio, F., Galbert, P. D., Habyarimana, J., \& Sabarwal, S. (2020). The impact of public-private partnerships on private school performance: Evidence from a randomized controlled trial in Uganda. Economic Development and Cultural Change, 68(2), 000-000.

[3] Billett, S. (2018). Student Readiness and the Integration of Experiences in Practice and Education Settings. In Integration of vocational education and training experiences (pp. 19-40). Springer, Singapore.

[4] Breathnach, C. \& Stephenson, F. (2011). A contribution to the discussion on participant readiness for action learning, Action Learning: Research and Practice, 8:3, 261-266, DOI: 10.1080/14767333.2011.617140

[5] Bridges, M. (1996). Improving Students' Readiness to Learn.

[6] Brigman, G. A., \& Webb, L. D. (2003). Ready to learn: Teaching kindergarten students school success skills. The Journal of Educational Research, 96(5), 286-292.

[7] Brunello, G., \& Rocco, L. (2008). Educational standards in private and public schools. The Economic Journal, 118(533), 1866-1887.

[8] Creswell, J. W. (2012). Research Design Pendekatan Kualitatif, Kuantitatif, dan Mixed. Yogyakarta: Pustaka Pelajar. Harsono.

[9] Dangol, R. \& Milan, S. (2019). Learning Readiness and Educational Achievement among School Students. The International Journal of Indian Psychology. 7. 467-476. $10.25215 / 0702.056$

[10] DiBenedetto, C. A., \& Myers, B. E. (2016). A Conceptual Model for the Study of Kesiapan Sekolah in the 21st Century. NACTA Journal, 60.

[11] Dronkers, J., \& Robert, P. (2008). Differences in scholastic achievement of public, private government-dependent, and private independent schools: A cross-national analysis. Educational Policy, 22(4), 541-577.

[12] Fidan, T., \& Oztürk, I. (2015). The relationship of the creativity of public and private school teachers to their intrinsic motivation and the school climate for innovation. Procedia-Social and Behavioral Sciences, 195, 905-914.

[13] Gee, K.A. (2015). Achieving gender equality in learning outcomes: evidence from a non-formal education program in Bangladesh. International Journal of Educational Development, 40: 207-216

[14] Grace, D. J., \& Brandt, M. E. (2006). Ready for success in kindergarten: A comparative analysis of teacher, parent, and administrator beliefs in Hawaii. Journal of Early Childhood Research, 4(3), 223-258.

[15] Grigoryeva, M. (2019). Students' Readiness For Changes As A Predictor Of Social Activity. 43-48. 10.15405/epsbs.2019.02.02.6.

[16] Hernandez, T. A., \& Cudiamat, M. A. (2018). Integrating Gender and Development (GAD) in the Classroom: The Case of Lucsuhin National High School, Department of Education-Philippines. KnE Social Sciences, 1135-1141.

[17] Hilferty, F., Redmond, G., \& Katz, I. (2010). The implications of poverty on children's readiness to learn. Australasian Journal of Early Childhood, 35(4), 63-71.
[18] Iqbal, M. (2012). Public versus private secondary schools: A qualitative comparison. Journal of Research and Reflections in Education, 6(1), 40-49.

[19] Jacobs, J. A. (1996). Gender inequality and higher education. Annual review of sociology, 22(1), 153-185.

[20] Janus, M., \& Duku, E. (2007). The school entry gap: Socioeconomic, family, and health factors associated with children's school readiness to learn. Early education and development, 18(3), 375-403.

[21] Jena, R. K. (2016): Investigating the interrelation between attitudes, learning readiness, and learning styles under virtual learning environment: a study among Indian students, Behaviour \& Information Technology, DOI: 10.1080/0144929X.2016.1212930

[22] Jensen, A. R. (1969). Understanding readiness: An occasional paper.

[23] Kartal, G., \& Balcikanli, C. (2019). Tracking the culture of learning and readiness for learner autonomy in a Turkish context. TEFLIN Journal, 30(1), 22-46.

[24] Katz, L. G. (1991). Readiness: Children and Schools. ERIC Digest.

[25] Kaymak, Z., \& Horzum, M. B. (2013). Relationship between online learning readiness and structure and interaction of online learning students. Educational Sciences: Theory and Practice, 13(3), 1792-1797.

[26] Kearney, W. S., \& Garfield, T. (2019). Student Readiness to Learn and Teacher Effectiveness: Two Key Factors in Middle Grades Mathematics Achievement. RMLE Online, 42(5), 1-12.

[27] Lema, J.D. \& Agrusa, J. (2007) Self-Efficacy, Industry Experience, and the Self-Directed Learning Readiness of Hospitality Industry College Students, Journal of Teaching in Travel \& Tourism, 6:4, 37-50, DOI: 10.1300/J172v06n04_03

[28] Mancebón, M. J., \& Muñiz, M. A. (2008). Private versus public high schools in Spain: Disentangling managerial and programme efficiencies. Journal of the operational Research Society, 59(7), 892-901.

[29] Mardati, A., Suyatno, \& Pambudi, D.I. (2019). Influence of Teacher Leadership and Teacher Values on Students Learning Readiness at Junior High School in Pangkalpinang City. International Journal of Scientific \& Technology Research. Volume 8(10), p. 3411-3416.

[30] Milanovic, I., \& Eppes, T. (2015). Improving student readiness for inquiry-based learning. In ASME/JSME/KSME 2015 Joint Fluids Engineering Conference. American Society of Mechanical Engineers Digital Collection.

[31] Moyer, K. (2011). The Impact on Student Achievement within Small Groups Based on Learning Styles, Interest, and Student Readiness. Online Submission.

[32] Mulyani, D. (2013). Hubungan kesiapan belajar siswa dengan prestasi belajar. Konselor, 2(1).

[33] Murray, E. \& Harrison, L.J. (2011): The influence of being ready to learn on children's early school literacy and numeracy achievement, Educational Psychology, 31:5,529-545 
[34] Oliver, L. N., Dunn, J. R., Kohen, D. E., \& Hertzman, C. (2007). Do neighbourhoods influence the readiness to learn of kindergarten children in Vancouver? A multilevel analysis of neighbourhood effects. Environment and Planning A, 39(4), 848-868.

[35] Payne, S. L., Flynn, J., \& Whitfield, J. M. (2008). Capstone business course assessment: Exploring student readiness perspectives. Journal of Education for Business, 83(3), 141-146.

[36] Perry, B., Dockett, S., \& Tracey, D. (1998). Ready to Learn: Exploring the Concept of School Readiness and Its Implications.

[37] Prakash, J. (2012). Brief notes on the Thorndike’s Laws of Learning. Preserve articles, Retrieved from http://www.preservearticles.com/201105206859/ throndikes-laws-of-learning.html

[38] Ramlan, M. I. S., Tahar, M. M., Yamin, N. A., \& Rani, J. (2019). Enhancing Learning Readiness and Interest of Special Education Students by Using Recreational Therapeutic Activities through Observation Methods. Jurnal Penelitian dan Pengembangan Pendidikan Luar Biasa, 5(2).

[39] Robbins, K. (2017). 21st Century Skills: Kesiapan sekolah, Opportunities, and Development (Master's Thesis, East Carolina University). Retrieved from the Scholarship. (http://hdl.handle.net/10342/6121.)

[40] Samarawickrema, R. G. (2005). Determinants of student readiness for flexible learning: Some preliminary findings. Distance education, 26(1), 49-66.

[41] Schnepf, S. V. (2004). Gender Equality in Educational Achievement: An East-West Comparison. IZA Discussion Paper No. 1317. Available at SSRN: https://ssrn.com/abstract=596942

[42] Starosta, V. (2019). Approaches to the essential characteristic of students' readiness for professional activity. Scientific Visnyk V.O. Sukhomlynskyi Mykolaiv National University. Pedagogical Sciences. 66. 232-237. 10.33310/2518-7813-2019-66-3-232-237.

[43] Curenton, S. M. (2010) Narratives as Learning Tools to Promote School Readiness, Early Education \& Development, 21:3, 287-292, DOI: 10.1080/10409289.2010.485532

[44] Suyatno, Pambudi, D.I., Mardati, A., Wantini, Nuraini, E., \&
Yoyo. (2019a). The Education Values of Indonesian Teachers: Origin, Importance, and Its Impact on Their Teaching. International Journal of Instruction, 12(3), 633-650. https://doi.org/10.29333/iji.2019.12338a

[45] Suyatno, Wantini, Baidi, \& Amurdawati, G. (2019b). The Influence of Values and Achievement Motivation on Teacher Professionalism at Muhammadiyah 2 High School Yogyakarta, Indonesia. The Journal of Pedagogika / Pedagogy t. 133, Nr. 1, p. 105-127

[46] Tomlinson, C. A., Brighton, C., Hertberg, H., Callahan, C. M., Moon, T. R., Brimijoin, K., \& Reynolds, T. (2003). Differentiating Instruction in Response to Kesiapan sekolah, Interest, and Learning Profile in Academically Diverse Classrooms: A Review of Literature. Journal for the Education of the Gifted, 27(2/3), 119-145.

[47] Tretyakova, N. V., Fedorov, V. A., Dorozhkin, E. M., Komarova, M. K., \& Sukhanova, E. I. (2016). Student Readiness Formation for Activities Oriented to Health Saving. International Journal of Environmental and Science Education, 11(15), 8281-8292.

[48] United Nations International Children’s Emergency Fund. (2002). articles, opinions, and research about teaching and learning. New York: Author. https://www.unicef.org/teache rs/learner/gender.htm

[49] United Nations International Children's Emergency Fund. (2012). A school readiness: A conceptual framework. New York: Author.

[50] Urquiola, M. (2016). Competition among schools: Traditional public and private schools. In Handbook of the Economics of Education (Vol. 5, pp. 209-237). Elsevier.

[51] Vasilevska, D., Rivza, B., \& Bogdan, R. (2017). Evaluation of Readiness for Distance Education of Students in European Universities. BRAIN. Broad Research in Artificial Intelligence and Neuroscience, 8(1), 35-41.

[52] Weinstein, S. E., \& Wu, S. W. (2009). Readiness assessment tests versus frequent quizzes: Student preferences. International Journal of Teaching and Learning in Higher Education, 21(2), 181-186.

[53] Xu, T., Byker, E. J., \& Gonzales, M. R. (2017). Ready to learn: The impact of the Morning Blast physical activity intervention on elementary school students. Malaysian Journal of Movement, Health \& Exercise, 6(1). 